Journal of Advanced Research in Fluid Mechanics and Thermal Sciences

\title{
Solid Oxide Fuel Cells Fueled with Biogas in Malaysia: A Review of Potential
}

\author{
Shafini Mohd Shafie ${ }^{1,}$, Zakirah Othman ${ }^{1}$, Norsiah Hami $^{1}$, Salmah Omar ${ }^{1}$, A Harits Nu'man ${ }^{2}$ \\ 1 School of Technology Management and Logistics, College of Business, Universiti Utara Malaysia 06010 Sintok, Kedah, Malaysia \\ Universitas Islam Bandung, Jalan Tamansari No. 20 Bandung 40116, West Java, Indonesia
}

\section{ARTICLE INFO ABSTRACT}

Article history:

Received 23 October 2020

Received in revised form 10 February 2021

Accepted 15 February 2021

Available online 11 March 2021
Keywords:

Solid oxide fuel cell; biogas; Malaysia; review

\begin{abstract}
The limitations of conventional energy resources have encouraged worldwide research on various types of energy in electricity generation. Fuel cell-based electricity generation creates a huge potential in the energy industry. This paper aimed to study the potential of biogas in Malaysia to be fed into the direct biogas solid oxide fuel cell (DB-SOFC) system. The data obtained from the Malaysian Palm Oil Board (MPOB), Energy Commission (ST) and Department of Statistics Malaysia were used in this study. The analysis showed that in 2019, Malaysia had the potential to generate biogas of about 877.53 million $\mathrm{m}^{3} /$ year. The characterizations of the DB-SOFC system with a capacity of $200 \mathrm{~kW}$ from Bloom Energy were applied in this study. The result indicated that Malaysia's potential to generate about 2006.9 MW of electricity from biogas solid oxide fuel cells was approximately $6 \%$ of the total electricity capacity in the country. When compared with the conventional biogas' combined production of heat and power (CHP), the DB-SOFC gave $76.95 \%$ more performance in electricity generation. Therefore, this study finding provides a positive impact on the biomass industry in Malaysia. Extensive research and development (R\&D) are needed in order to penetrate this fuel cell system into Malaysia's energy industry landscape.
\end{abstract}

\section{Introduction}

Malaysia is highly dependent on non-renewable energy resources, whereby in $2016,48 \%$ of electricity was generated from coal, $38 \%$ electricity was from natural gas, and the rest of electricity was from hydropower with other forms of renewable energy resources [1]. Malaysia is highly dependent on fossil fuels in electricity generation. Therefore, the increasing global coal price will increase the pressure on the power generation industry, consequently affecting the increase in electricity price in Malaysia [2]. This is because coal is completely imported into Malaysia, in which $63 \%$ of coal is imported from Indonesia, $24 \%$ is from Australia, $11 \%$ is from Russia, and $2 \%$ is from South Africa [2]. Besides, the emission of carbon dioxide is increasing due to the increasing use of fossil fuels for electricity generation [3]. Furthermore, Malaysia will face the issue of fossil fuel depletion in the future due to the increasing energy demand.

\footnotetext{
* Corresponding author.

E-mail address: shafini@uum.edu.my

https://doi.org/10.37934/arfmts.81.1.1825
} 
Malaysia has very big potential to develop the biogas industry [4]. It is the second largest manufacturer in the world, which contributes 2.05 million tonnes of the world's palm oil production [5]. This is due to Malaysia being a tropical country that receives an average of 250 centimetres of rainfall per year that is suitable for oil palm plantation [6]. The types of waste produced from palm oil manufacture processes are such as empty fruit bunches (EFB), palm oil mill effluents (POME), palm kernel shells (PKS), oil palm leaves (OPL), and oil palm fronds (OPF). According to [7], as Malaysia is one of the main producers of palm oil biomass sources for bioenergy production, there is a crucial need to thoroughly certify the sustainability of biogas production from POME. The anaerobic digestion of POME produces another valuable product that is biogas. Biogas can reduce the dependence on fossil fuels and replace them because it contains methane and is sufficient to generate electricity and heat. About $75 \%$ of palm oil waste are left to rot in oil palm tree plantations for nutrient recycling, while the remaining $25 \%$ palm oil waste in the forms of EFB and PKS are directly burned to generate electricity for palm oil mills [8].

Biogas is an alternative renewable energy resource. It is produced from anaerobic digestion rather than the fossil fuels from geological process [9]. Biogas can reduce dependence and replace fossil fuels because it contains methane and it sufficients to generate electricity and heat. Biogas can also be used to fuel the gaseous car to move [10]. Besides, biogas can produce biomethane. Biomethane is consisting of $98 \%$ methane, which is produced by removing water hydrogen sulphide, nitrogen, oxygen, ammonia, siloxanes and particulates. Biomethane have potential economic opportunities in certain areas can replace natural gas to produce chemical product [10].

Biogas is a gas that consists mainly of methane, carbon dioxide, and slight amounts of nitrogen and hydrogen. However, only a small amount of palm oil waste is processed to produce biogas because it is still not fully developed in Malaysia [11]. The Energy Commission recorded that Malaysia had less than $1 \%$ electricity generated using biogas in 2016. Therefore, biogas is a very potential energy resource to be utilised by the country. Biogas is a biofuel that produced from the microbial fermentation of organic waste [7]. It is gas that produced by the organic substrates under the anaerobic environment, among the complicated organic matter is decomposed by anaerobic bacteria. The biogas consists approximately of 55 to $70 \%$ methane, 30 to $45 \%$ carbon dioxide and other trace gases such as oxygen, carbon monoxide and hydrogen sulphide [12]. When the organic waste disposed in an environment that absent of oxygen, they will be decomposed and released the biogas. The process is called anaerobic digestion. Besides, biogas is carbon neutral because the carbon of the biogas is from the organic waste that fixed from atmosphere carbon dioxide. Therefore, carbon dioxide will not increase although burning biogas will release carbon dioxide. In addition, the organic wastes will sustain to grow and available, which means it is highly sustainable.

\subsection{Anaerobic Digestion}

Anaerobic digestion is one of the thermal processes. Anaerobic digestion is a biological process that turns biodegradable matters into methane and carbon dioxide by numerous microorganisms in the environment without oxygen [13]. There are 4 stages in anaerobic digestion, which are hydrolysis, acidosis, acetogenesis, and methanogenesis [13]. Figure 1 show the Anaerobic process for biogas production. 


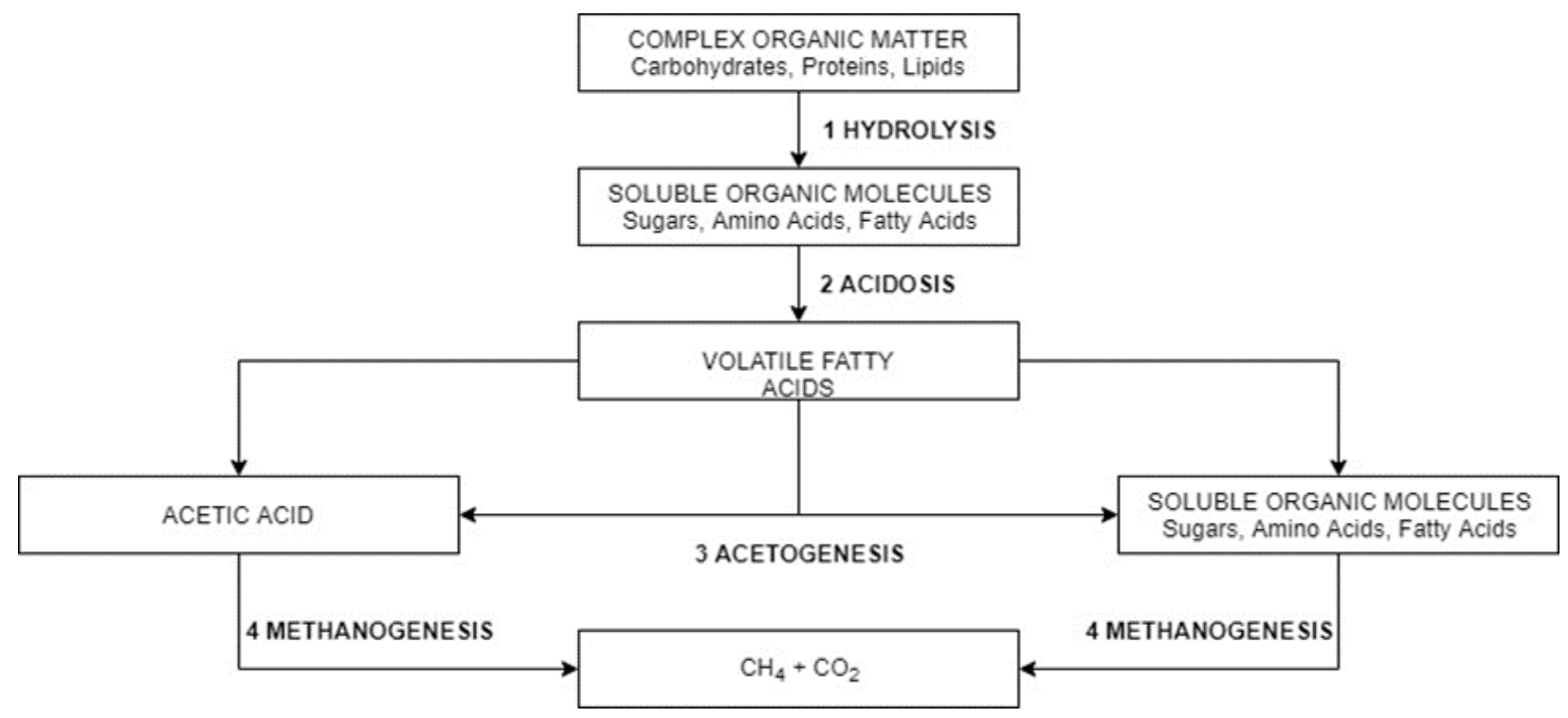

Fig. 1. Anaerobic process for biogas production

\subsection{Fuel Cell}

Fuel cell is a device that converts hydrogen or gas into electricity through chemical reaction. Dissimilar with a battery that needs to be charged regularly, fuel cells can continuously produce electricity as long as the energy resource is provided. Several foreign companies such as Fuel Cell Energy, a USA fuel cell company, have successfully developed biogas to power fuel cells. Byucksan Engineering is the first successful case of utilising biogas-fed fuel cells in a used water treatment plant in Busan to generate electricity in Korea [19]. Typically, there have several types of fuel cell like solid oxide fuel cell (SOFC), polymer electrolyte membrane fuel cell (PEMFC), carbonate-based electrolyte fuel cell (MCFC), alkaline fuel cell (AFC), phosphoric acid fuel cell (PAFC), and direct methanol fuel cell (DCFC). Each of them has different application for example PEMFC most suitable for transportation application. High flexibility of SOFC make it applicable for variety of gas including biogas [20].

The Malaysian government proposes the initiative to increase the consumption of renewable energy in energy mix through several programs such as Small Renewable Energy Power Program (SREP), Biomass-Based Power Generation and Cogeneration in the Palm Oil Industry (BioGen) project, and research by the Federal Land Development Authority (FELDA) [7]. From the year 2000, Malaysia has run several energy policies to promote as well as improve the utilisation of renewable energy resource in the country. Table 1 shows the energy policies in Malaysia.

Table 1

Energy policies in Malaysia

\begin{tabular}{ll}
\hline Year & Policy \\
\hline 1975 & National Petroleum Policy \\
1979 & National Energy Policy \\
1980 & National Depletion Policy \\
1981 & Four-Fuel policy \\
2001 & Five-Fuel policy \\
2006 & National Biofuel Policy \\
2010 & National Renewable Energy Policy and Action Plan \\
\hline
\end{tabular}

This study estimates biogas data on the actual production and future potential and presents the potential of electricity generation by using direct biogas solid oxide fuel cells (DB-SOFC). 


\section{Methodology}

This study starts with calculated the potential of biogas production from palm oil waste especially the POME. At the same time, identify the available fuel cell that most suitable for operating with biogas. The process diagram is showed in Figure 2.

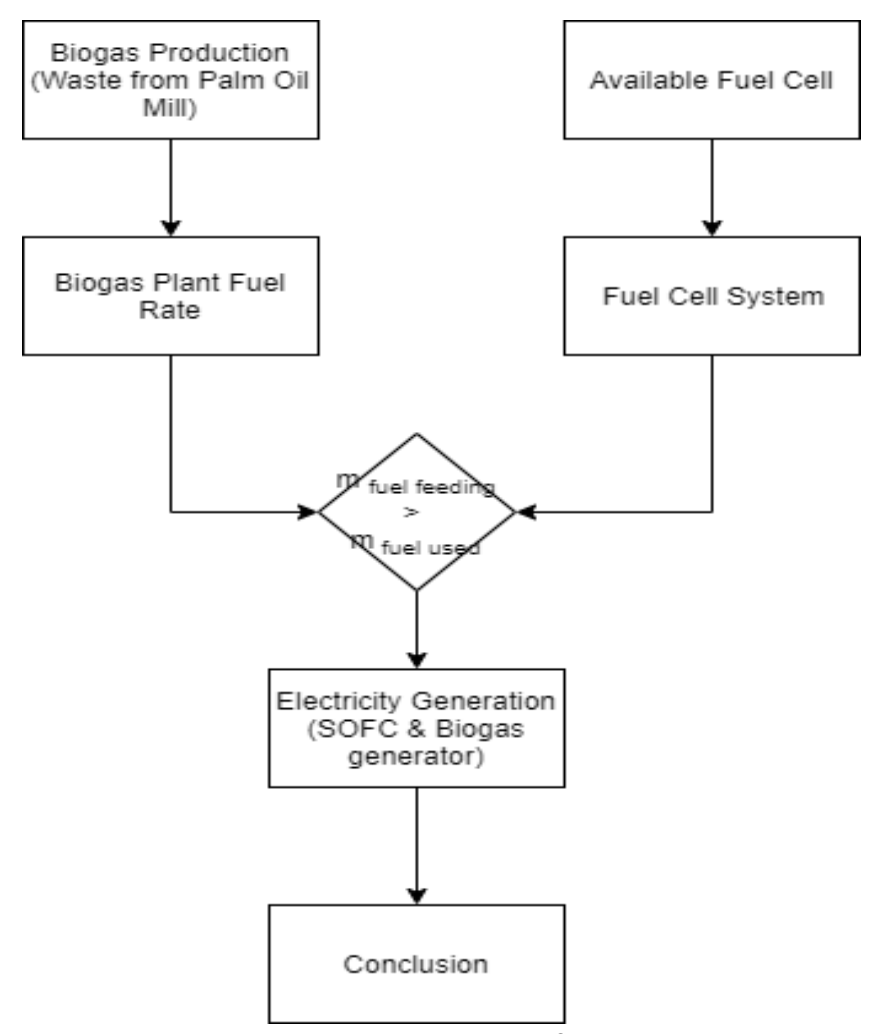

Fig. 2. Process diagram of the study

The data used in this study were obtained from the Malaysian Palm Oil Board (MPOB) [5], Energy Commission [1], and Department of Statistics Malaysia [21]. In estimating the electricity generation from fuel cells, Eq. (1) until Eq. (4) from this literature [22] are used in this study. The parameters applied in this study are listed in Table 2 below.

$\xi_{B I O G A S}=M_{B I O G A S} / t$

$t=E / P$

$M_{B I O G A S}=Q / L H V$

$Q=B T U / \eta_{\text {SOFC }}$

\section{Table 2}

Parameters applied in this study

\begin{tabular}{lll}
\hline Parameter & Value & Reference \\
\hline Caloric value of biogas & $53000 \mathrm{kcal} \mathrm{m}^{-3}$ & {$[23]$} \\
Low heating value of biogas & $22.19 \mathrm{MJ} \mathrm{kg}^{-1}$ & {$[24]$} \\
Fuel cell efficiency & $60 \%$ & {$[25]$} \\
Heat rate in BTU & 6295 & {$[22]$} \\
\hline
\end{tabular}


It is assumed that one tonne of crude palm oil will produce about 2.5 tonnes of POME [26]. In this study, the ratio of biogas and POME is set at 35 [27]. The plant operating in this study is estimated the whole year.

\section{Results and Discussions}

In 2019, Malaysia could produce about $134 \mathrm{MW}$ of plant capacity by using biogas as the main fuel in boilers. Currently, Malaysia only generates about $45.01 \mathrm{MW}$ of biogas plant capacity [28]. It means that only $33.5 \%$ of biogas from palm oil waste is being utilised in the country's electricity generation. This is a huge potential in feeding the unused biogas into the fuel cell system. Figure 3 shows the production of biogas and plant capacity from 2014 to 2019.

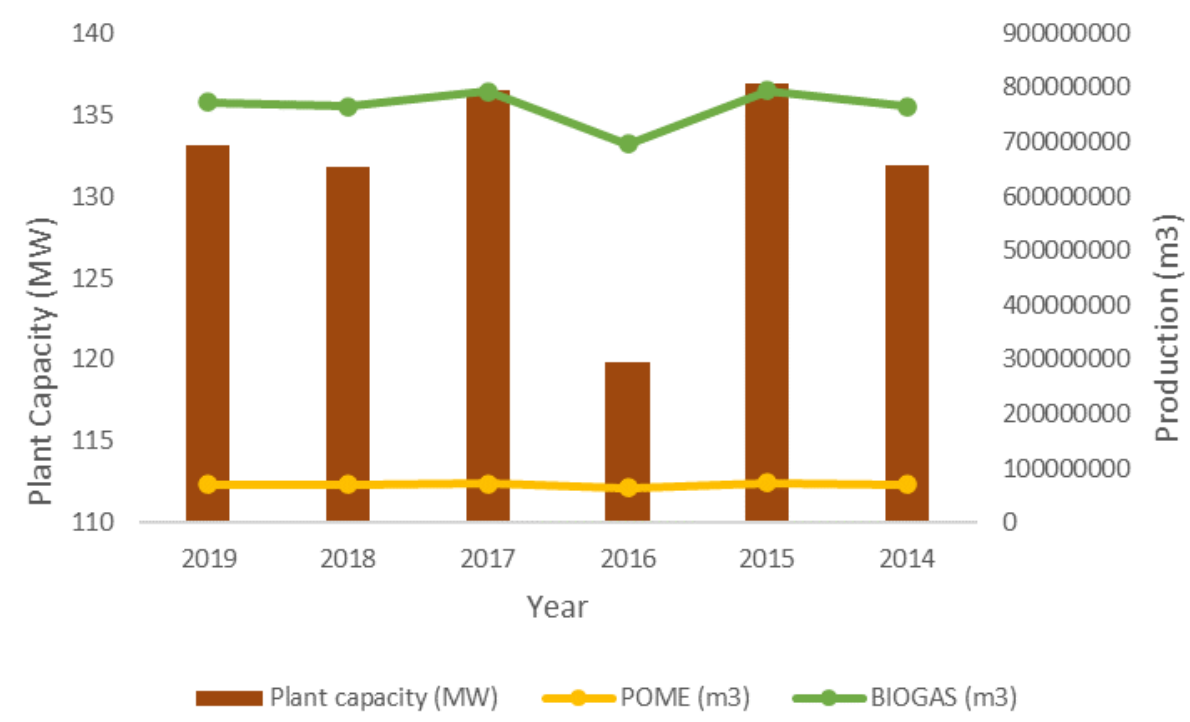

Fig. 3. The production of biogas and plant capacity

Figure 4 demonstrates Malaysia's electricity generation capacity and electricity generated by DBSOFC. It indicates that the country installed electricity generation capacity from 2014 up to 2018. It seems that fuel cells could potentially contribute up to $5.5 \%$ of the total electricity generation mix in the country. Fully utilising the available POME for biogas production into the fuel cell system could achieve the target of fuel cells in electricity generation to produce about $3000 \mathrm{GWh}$ in the year 2035 [29].

The highest installed capacity was 1007.94 MW of electricity in the state of Sabah. Peninsular Malaysia had the potential to generate $2117.83 \mathrm{MW}$ of electricity. Figure 5 shows the state potential of installed capacity in biogas fed solid oxide fuel cells.

It shows that the DB-SOFC performance was $76.95 \%$ higher as compared to biogas-based electricity generation in Malaysia. However, blending other biomass resources in producing biogas could increase the number of plant capacity in certain states. For example, more research needs to be conducted on blending paddy waste in Kedah to generate biogas. Figure 6 demonstrates the performance comparison between biogas and DB-SOFC based electricity generation for each state in Malaysia. Fuel cells provide high efficiency in electricity generation as compared to the conventional type of biogas in producing electricity. 


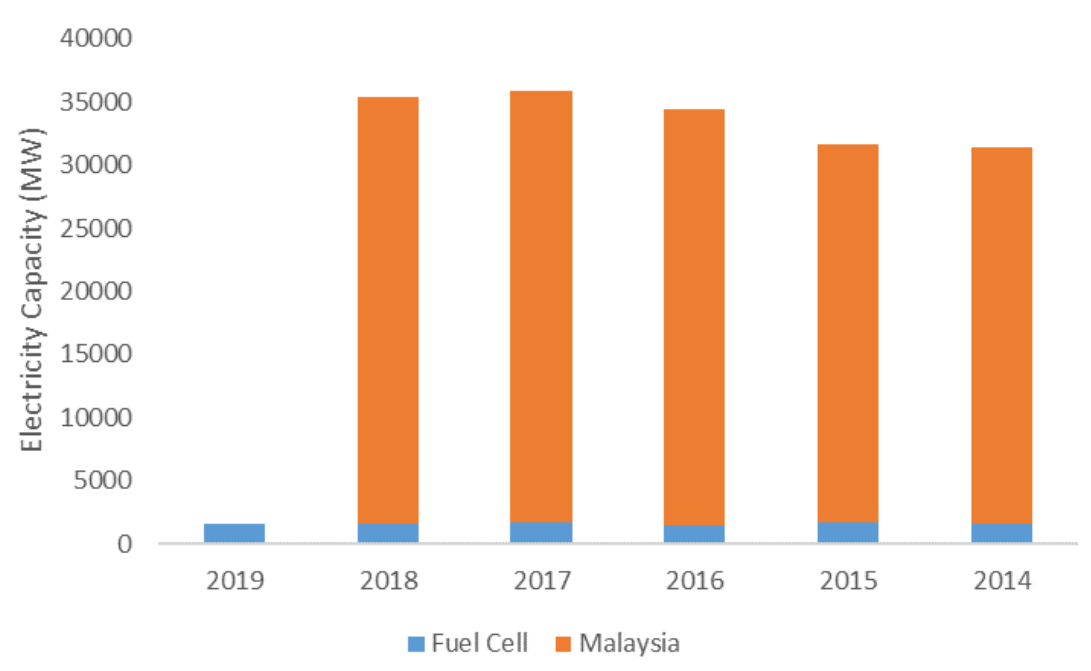

Fig. 4. Malaysia's electricity generation capacity and electricity generated by DB-SOFC

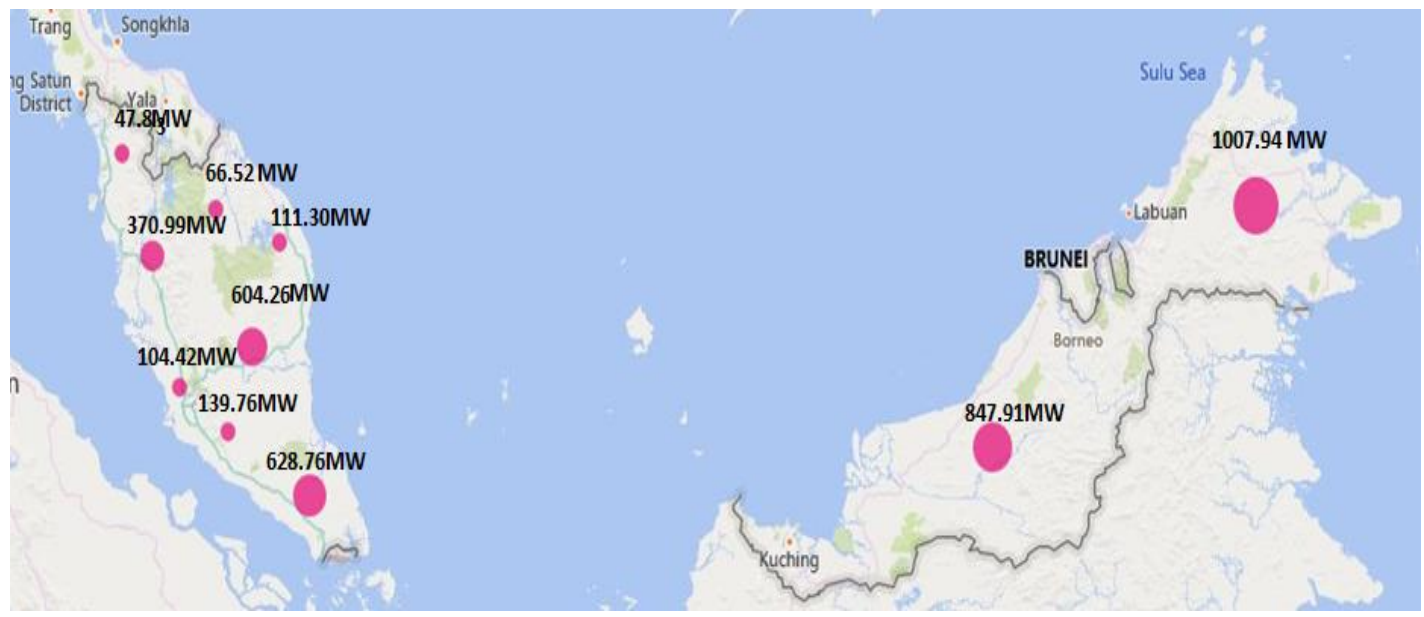

Fig. 5. State potential of installed capacity in biogas fed solid oxide fuel cells

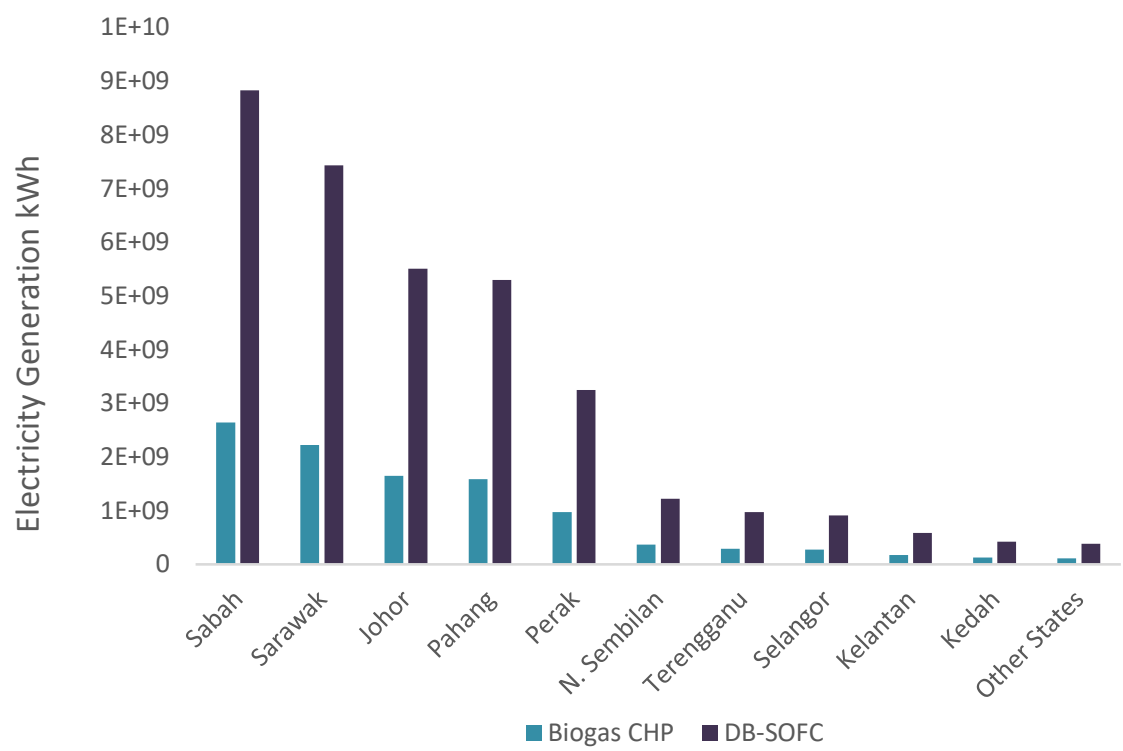

Fig. 6. Performance comparison between biogas and DB-SOFC based electricity generation for each state in Malaysia 


\section{Conclusion}

In 2019, Malaysia potentially generated biogas of about 877.53 million $\mathrm{m}^{3} /$ year. Therefore, Malaysia has the potential to generate about 2006.9 MW of electricity from biogas solid oxide fuel cells, which amounts to approximately $6 \%$ of the total electricity capacity in the country. Sabah is the highest state that potentially applied for DB-SOFC. When compared with the conventional biogas' combined production of heat and power (CHP), the DB-SOFC gave $76.95 \%$ more performance in electricity generation. More aspects such as technology, economic, and cost are needed to be considered in future research even though the capability in terms of resources is fulfilled in Malaysia. The penetration of fuel cells in Malaysia's electricity generation mix greatly needs strong support from the government by implementing a new policy towards a sustainable country.

\section{Acknowledgements}

This research was financially supported by the Ministry of Higher Education Malaysia (FRGS14199/2018). The authors would like to thank the reviewers and associate editor for their comments that have improved this manuscript.

\section{References}

[1] MEIH. Malaysia Energy Information Hub. 2020 [cited 202028 Feb 2020]; Available from: https://meih.st.gov.my/statistics;jsessionid=FC2A9BB8A44B13BB6AB1E866190BCC0F

[2] H., L., High Coal Prices Putting Pressure on Malaysia Power Sector., in The Star Online2018, The Star: Kuala Lumpur.

[3] Safaai, Nor Sharliza Mohd, Zainura Zainon Noor, Haslenda Hashim, Zaini Ujang, and Juhaizah Talib. "Projection of CO2 emissions in Malaysia." Environmental Progress \& Sustainable Energy 30, no. 4 (2011): 658-665. https://doi.org/10.1002/ep.10512

[4] Chia, L., What is Malaysia's Biomass and Biogas Potential and How Far are We from Realising it?, in T. Edge2019.

[5] MPOB. Production. 2020 [cited 20204 April 2020]; Available from: http://bepi.mpob.gov.my/index.php/en/?option=com content\&view=category\&id=106

[6] Hosseini, Seyed Ehsan, and Mazlan Abdul Wahid. "Feasibility study of biogas production and utilization as a source of renewable energy in Malaysia." Renewable and Sustainable Energy Reviews 19 (2013): $454-462$. https://doi.org/10.1016/i.rser.2012.11.008

[7] Aziz, Nur Izzah Hamna A., Marlia M. Hanafiah, and Shabbir H. Gheewala. "A review on life cycle assessment of biogas production: Challenges and future perspectives in Malaysia." Biomass and Bioenergy 122 (2019): $361-374$. https://doi.org/10.1016/j.biombioe.2019.01.047

[8] Awalludin, Mohd Fahmi, Othman Sulaiman, Rokiah Hashim, and Wan Noor Aidawati Wan Nadhari. "An overview of the oil palm industry in Malaysia and its waste utilization through thermochemical conversion, specifically via liquefaction." Renewable and Sustainable Energy Reviews 50 (2015): 1469-1484. https://doi.org/10.1016/i.rser.2015.05.085

[9] Badurek, C.A. Biogas. 2018 [cited 2020 January 20]; Available from: https://www.britannica.com/technology/biogas

[10] Weiland, Peter. "Biogas production: current state and perspectives." Applied microbiology and biotechnology 85, no. 4 (2010): 849-860. https://doi.org/10.1007/s00253-009-2246-7

[11] Malaysian-German Chamber of Commerce and Industry (MGCC). "Oil palm biomass and biogas in Malaysia, 2017." (2017).

[12] Deublein, D., and A. Steinhauser. "Biogas from waste and renewable resources, A John Wiley and Sons." Inc., Publication (2008). https://doi.org/10.1002/9783527621705

[13] Liu, Ting, Xiaoqin Zhou, Zifu Li, Xuemei Wang, and Jiachen Sun. "Effects of liquid digestate pretreatment on biogas production for anaerobic digestion of wheat straw." Bioresource technology 280 (2019): $345-351$. https://doi.org/10.1016/j.biortech.2019.01.147

[14] Rogoff, Marc J., and Francois Screve. Waste-to-energy: technologies and project implementation. Academic Press, 2019. https://doi.org/10.1016/B978-1-4377-7871-7.10002-4

[15] Li, Yebo, Stephen Y. Park, and Jiying Zhu. "Solid-state anaerobic digestion for methane production from organic waste." Renewable and sustainable energy reviews 15, no. 1 (2011): $821-826$. https://doi.org/10.1016/j.rser.2010.07.042 
[16] Angelidaki, Irini, Dimitar Karakashev, Damien J. Batstone, Caroline M. Plugge, and Alfons JM Stams. "Biomethanation and its potential." In Methods in enzymology, vol. 494, pp. 327-351. Academic Press, 2011. https://doi.org/10.1016/B978-0-12-385112-3.00016-0

[17] Pecchi, Matteo, and Marco Baratieri. "Coupling anaerobic digestion with gasification, pyrolysis or hydrothermal carbonization: A review." Renewable and Sustainable Energy Reviews 105 (2019): $462-475$. https://doi.org/10.1016/i.rser.2019.02.003

[18] Chen, Ye, Jay J. Cheng, and Kurt S. Creamer. "Inhibition of anaerobic digestion process: a review." Bioresource technology 99, no. 10 (2008): 4044-4064. https://doi.org/10.1016/i.biortech.2007.01.057

[19] POSCO Energy. Fuel Cell Product. 2018 [cited 202011 January 2020]; Available from: http://eng.poscoenergy.com/ service/business/battery/product dfc3000.asp

[20] De Arespacochaga, N., C. Valderrama, C. Peregrina, A. Hornero, Lynne Bouchy, and J. L. Cortina. "On-site cogeneration with sewage biogas via high-temperature fuel cells: Benchmarking against other options based on industrial-scale data." Fuel Processing $\quad$ Technology $138 \quad$ (2015): https://doi.org/10.1016/i.fuproc.2015.07.006

[21] Department of Statistics Malaysia. Time Series Data. 2015 [cited 202028 January 2020]; Available from: https://www.dosm.gov.my/v1/index.php?r=column/ctimeseries\&menu id=NHJlaGc2Rlg4ZXIGTjh1SU1kaWY5UT0 $\underline{9}$

[22] Saengprajak, Arnusorn, Aree Katcharoen, Wutthisat Chockua, and Jenjira Piamdee. "Prospective study of application the direct-biogas solid oxide fuel cell system to the biogas plant in Thailand." Energy Procedia 158 (2019): 978-983. https://doi.org/10.1016/i.egypro.2019.01.239

[23] MPOB. Oil Palm \& The Environment (updated March 2014). 2014 [cited 202018 May 2020]; Available from: http://palmoilis.mpob.gov.my/V4/oil-palm-the-environment/

[24] Hosseini, Seyed Ehsan, and Mazlan Abdul Wahid. "Feasibility study of biogas production and utilization as a source of renewable energy in Malaysia." Renewable and Sustainable Energy Reviews 19 (2013): $454-462$. https://doi.org/10.1016/i.rser.2012.11.008

[25] Andersson, M. A. R. T. I. N., and B. E. N. G. T. Sunden. "Technology review-solid oxide fuel cell." Energiforsk $A B$ (2017).

[26] Hassan, Mohd Ali, and Suraini Abd-Aziz. "Waste and Environmental Management in the Malaysian Palm Oil Industry." In Palm Oil, pp. 693-711. AOCS Press, 2012. https://doi.org/10.1016/B978-0-9818936-9-3.50026-5

[27] Azahari, M.N., Biogas Production at Green Lagoon Technology Sdn Bhd, 2019: Kedah.

[28] Shafie, Shafini Mohd, Z. Othman, N. Hami, and S. Omar. "The Potential of using Biogas Feeding for Fuel Cells in Malaysia." International Journal of Energy Economics and Policy 10, no. 1 (2020): 109. https://doi.org/10.32479/ijeep.8373

[29] Shafie, SM. "Potential Use of Fuel Cell As Electricity Generation in Malysia: A Review*". International Journal of Advanced Science and Technology 28 (2019): 772 -776. https://doi.org/10.1080/14442213.2016.1208676 